\title{
EFEKTIVITAS KOMUNIKASI INTERPERSONAL DALAM KEGIATAN PEMBELAJARAN MELALUI MEDIA WHATSAPP GROUP
}

Oleh:

\author{
SEPRIADI SAPUTRA
}

Universitas Islam Negeri Raden Fatah Palembang

\begin{abstract}
This study aims to know the effectivity of interpersonal communication in learning activities through WhatsApp Group Media, a research study using an effectiveness study proposed by Devito (1997) which says there are 5 general dimensions to measure the effectiveness of interpersonal communication activities including openness, empathy, supportive, attitude positive and equality. Based on the results of the presentation about the effectiveness of interpersonal communication in lectures using WhatsApp Group by the Communication Studies lecturer at the Raden Fatah State Islamic University of Palembang, it is known that WhatsApp Group can display various types of learning media in the form of visual media, audio, audio visual, and presenter groups. However, the WhatsApp group media cannot provide sample objects directly if the course requires sample objects to be demonstrated. This research shows that learning activities that only use WhatsApp Group media without using face-to-face lecture methods are ineffective, this is due to the many obstacles faced by students and lecturers when the lecture activities take place. Various obstacles faced are the small level of openness of students, empathy that is difficult to show both by students and by lecturers, the attitude of support is not as strong as learning is done by direct meeting in class, the attitude shown is largely the opposite of what is expected by the lecturer, as well as the equality of the meaning of learning materials both for students and for different lecturers.
\end{abstract}

Keywords: interpersonal communication, openness, empathy, supportiveness, positive attitude and equality, whatsapp group

\section{PENDAHULUAN}

Seluruh dunia tidak terkecuali di Indonesia dilanda musibah pandemi virus corona yang mengakibatkan jutaan orang diseluruh dunia terinveksi virus corona dan tidak pelak virus ini juga berdampak pada kematian ataupun penyakit yang mematikan bagi manusia yang tertular oleh virus ini.

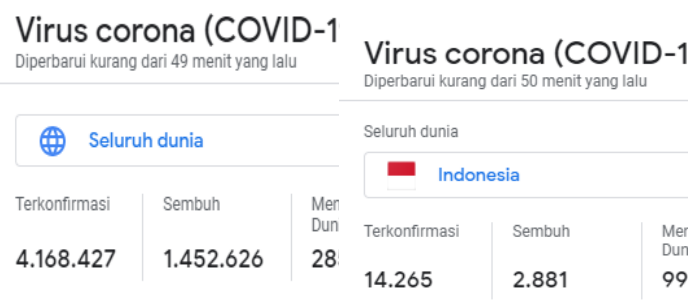

Gambar 1. Data Statistik Penyebaran Virus Corona 12 Mei 2020

Sumber :

https://news.google.com/covid19, 2020 
Berdasarkan data pada gambar diatas, banyaknya kasus penyebaran virus korona membuat seluruh pemerintah di dunia harus membuat kebijakan secepat mungkin untuk menghentikan penyebaran virus tersebut. Sehingga berbagai kegiatan seperti bekerja, sekolah, dan seluruh aktifitas yang mengharuskan manusia melakukan perkumpulan harus dihentikan untuk sementara waktu. Menurut Fitriah (2020) Pandemi Covid-19 berdampak besar pada berbagai sektor, salah satunya pendidikan. Dunia pendidikan juga ikut merasakan dampaknya Pendidik harus memastikan kegiatan belajar mengajar tetap berjalan, meskipun peserta didik berada di rumah. Solusinya, pendidik dituntut mendesain media pembelajaran sebagai inovasi dengan memanfaatkan media daring (online). Ini sesuai dengan Menteri Pendidikan dan Kebudayaan Republik Indonesia terkait Surat Edaran Nomor 4 Tahun 2020 tentang Pelaksanaan Kebijakan Pendidikan dalam Masa Darurat Penyebaran Corona Virus Disease (Covid-19).

Fitria (2020) juga menyebutkan bahwa sistem pembelajaran dilaksanakan melalui perangkat personal computer (PC) atau laptop yang terhubung dengan koneksi jaringan internet. Pendidik dapat melakukan pembelajaran bersama di waktu yang sama menggunakan grup di media sosial seperti WhatsApp, telegram, instagram, aplikasi Zoom ataupun media lainnya sebagai media pembelajaran.

Berangkat dari permasalahan tersebut maka tidak dapat dipungkiri bahwa setiap siswa yang masih mengenyam pendidikan baik itu tingkat SD, SMP, SMA bahkan mahasiswa harus merubah kebiasaan belajar disekolah menjadi belajar dari rumah dengan berbagai fasilitas teklologi ada, dan salah satuh fasilitas teknologi yang harus dimiliki selain PC dan Laptop adalah smartphone atau telepon pintar. Telepon pintar atau smartphone saat ini bukan hanya bisa melakukan aktifitas pesan SMS, atau regular telepon saja, akan tetapi telepon pintar saat ini memiliki akses internet sehingga telepon pintar saat ini dapat memiliki berbagai fitur aplikasi mutakhir untuk memudahkan bertatap muka dan melakukan chatting group dengan biaya yang sangat rendah. Menurut Severin James (2011), smartphone yang disebut sebagai komputer saku tersebut memiliki kegunaan untuk mengakses situs jejaring sosial, newsgroup, mailing lists, googling, searching, dan membuka website dengan bantuan internet.

Salah satu aplikasi yang paling popular saat ini adalah aplikasi WhatsApp, dimana aplikasi ini dapat melakukan berbagai aktifitas komunikasi dengan aman, nyaman dan mudah hanya menggunakan satu aplikasi saja, Untari (2020) dalam artikelnya menyebutkan bahwa WhatsApp menjadi aplikasi chat paling populer saat ini. Aplikasi ini kabarnya digunakan oleh 1,5 miliar pengguna diseluruh dunia. Bahkan menurut laporan Sensor Tower, WhatsApp menjadi aplikasi yang paling banyak diunduh di Play Store dan App Store selama 2019. Untuk diketahui, WhatsApp awalnya didirikan oleh dua mantan karyawan Yahoo!, Brian Acton dan Jan Koum. Aplikasi kemudian diluncurkan pertama pada November 2009, setelah pengujian. Awalnya, WhatsApp hanya eksklusif hadir di App Store.

Mengingat banyaknya pengguna WhatsApp berdasarkan pemaparan dalam artikel yang dipaparkan oleh Untari tersebut, maka WhatsApp layak untuk digunakan sebagai salah satu media yang digunakan oleh siswa untuk melaksanakan kegiatan belajar, karena berdasarkan data tersebut dapat disimpulkan bahwa para siswa sudah familiar dan mengetahui aplikasi WhatsApp dan sudah terbiasa untuk menggunakannya. WhatsApp sendiri menyediakan berbagai fitur yang dapat memudahkan kegiatan belajar mengajar, dan salah satu fiturnya adalah WhatsApp Group, dengan menggunakan WhatsApp Group maka seorang guru atau pendidik dapat mengumpulkan murid dalam jumlah yang banyak dalam satu ruang chat, sehingga siswa dapat berinteraksi dengan mudah baik 
itu menggunakan voice note, text, video atau gambar.

Trisnani (2017) dalam jurnalnya yang berjudul "Pemanfaatan WhatsApp sebagai Media Komunikasi dan Kepuasan dalam Penyampaian pesan di Kalangan Tokoh Masyarakat" mengatakan bahwa WhatsApp paling dominan digunakan. Pada saat ini, WhatsApp telah dimanfaatkan oleh tokoh masyarakat untuk berkomunikasi dalam menyampaikan pesan kepada sasarannya, Saat ini meskipun masih berkomunikasi secara langsung. Tokoh masyarakat memanfaatkan WhatsApp sebagai media komunikasi dalam menyampaikan pesan, informasi yang disampaikan lebih efektif dan merupakan kepuasan tersendiri karena menggunakan teknologi informasi (WhatsApp) pesan lebih cepat diterima kepada sasaran. Isi pesan; adalah; keamanan lingkungan, ikatan sosial, pendidikan, kesejahteraan dan pekerjaan serta hiburan.

Berdasarkan hasil penelitian yang dilakukan Trisnani maka WhatsApp sudah memberikan kontribusi efektif untuk melakukan penyampaian pesan yang efektif dan mudah kepada seluruh tokoh masyarakat ini artinya tidak menutup kemungkinan bahwa WhatsApp juga dapat efektif apabila digunakan untuk kegiatan pembelajaran kepada siswa pada saat pandemi Corona. Penelitian lain yang mendukung adalah penelitian yang dilakukan oleh sartika (2018), yang mengatakan bahwa bahwa kegunaan WhatsApp smartphone sebagai media informasi sangat berperan dalam memberikan serta menyebarkan informasi ke orang lain. Serta dalam perkuliahan kegunaan WhatsApp smartphone sebagai sarana berkomunikasi baik pemeberian materi mata kuliah yang berupa penjelasan bila dalam kelas mahasiswa kurang memahami materi saat dalam proses belajar mengajar dalam kelas. Tidak hanya itu kegunaaan WhatsApp juga untuk penyempurna sarana pengiriman tugas dari dosen ke mahasiswa karena dari segi waktu sangat efisien tidak terlalu lama tugas perkuliahan dapat terkirim dengan mudah dan segera diterima oleh dosen yang bersangkutan. Semenjak pemerintah mengeluarkan kebijakan untuk melaksanakan kegiatan perkuliahan dari rumah maka dosen program studi Ilmu Komunikasi langsung membuat WhatsApp Group untuk setiap mata kuliah yang diampuhnya, sehingga seluruh mahasiswa dapat tetap terkoneksi dengan dosen pengampu mata kuliah dan melakukan kegiatan belajar secara daring. Berdasarkan hasil observasi yang dilakukan selain kemudahan pengiriman media belajar, seperti materi berupa video, voice note, gambar dan teks mahasiwa dan dosen juga mengalami beberapa kendala yang dihadapi, seperti koneksi signal yang terkadang terputus, terlewatnya chat yang masuk, dan sulitnya untuk berinteraksi dan mengekspresikan berbagai contoh seperti yang dilakukan saat komunikasi secara langsung membuat hasil belajar tidak seefektif kegiatan pembelajaran saat melaksanakan kegiatan perkuliahan secara tatap muka.

Berbagai masalah yang muncul menimbulkan penafsiran apakah kegiatan komunikasi dalam perkuliahan menggunakan WhatsApp Group efektif atau tidak sehingga diperlukan kajian yang lebih dalam untuk menemukan hambatan dan dapat ditindaklanjuti solusinya. Berdasarkan latar belakang yang sudah dipaparkan tersebut maka peneliti hendak membahas sejauh mana efektifitas komunikasi dalam kegiatan belajar apabila hanya menggunakan media WhatsApp Group tanpa adanya pertemuan tatap muka.

\section{Komunikasi}

Komunikasi menurut Effendy (2002) dalam bahasa inggris yaitu communication, berasal dari kata Latin communication, dan bersumber dari kata communis yang berarti sama. Maksudnya adalah sama makna, hal ini mengindikasikan bahwa setiap kegiatan komunikasi dilakukan untuk mencapai persamaan makna bagi komunikator dan komunikan. 
Carl I. Hovland dalam Effendy (2002) juga mendefinisikan komunikasi sebagai "The process by which an individual (the communicator) transmits stimuli (usually verbal symbols) to modify the behavior of other individuals (communicatees)." (Proses dimana seseorang (komunikator) menyampaikan perangsang (biasanya lambang bahasa) untuk mengubah perilaku orang lain (komunikan). Pada pengertian yang dikemukakan oleh Carl, komunikasi diartikan sebagai proses dalam menyampaikan pesan yang sebagian besar pesannya berada dalam bentuk bahasa baik lisan maupun tulisan untuk mengubah perilaku.

Banyak pengertian komunikasi yang dikemukakan para ahli salah satunya penegrtian komunikasi yang dikemukakan oleh Mulyana, yang dirangkum dari berbagai definisi pengertian komunikasi menurut para ahli, diantaranya adalah :

1. Everett M.Rogers, Komunikasi adalah proses dimana suatu ide dialihkan dari sumber kepada suatu penerima atau lebih, dengan maksud untuk merubah tingkah laku mereka.

2. Theodore M.Newcomb, Komunikasi merupakan setiap tindakan komunikasi dipandang sebagai suatu transmisi informasi, terdiri dari rangsangan yang diskriminatif, dari sumber kepada penerima.

Berdasarkan pengertian komunikasi menurut para ahli tersebut dapat diketahui bahwa komunikasi merupakan bagian penting dalam hidup manusia, dimana kegiatan komunikasi merupakan kegiatan dalam proses pertukaran informasi baik itu berupa rangsangan diskriminatif, untuk mengubah perilaku penerima pesan dalam bentuk pemahaman atau tindakan. komunikasi dalam penelitian ini merupakan bentuk penyampaian informasi pembelajaran yang dilakukan menggunakan media WhatsApp Group untuk mendapatkan persamaan persepsi bagi mahasiswa yang menerima materi pembelajaran sehingga mahasiswa paham mengenai maksud dari materi pembelajaran yang disampaikan melalui media group WhatsApp.

\section{Smart Phone dan WhatsApp}

Ponsel cerdas atau smartphone adalah telepon genggam yang mempunyai kemampuan dengan pengguna dan fungsi yang menyerupai komputer. Belum ada standar pabrik yang menentukan arti ponsel cerdas. Bagi beberapa orang, ponsel cerdas merupakan telepon yang bekerja menggunakan seluruh perangkat lunak sistem operasi yang menyediakan hubungan standar dan mendasar bagi pengembangan aplikasi. Bagi yang lainnya, ponsel cerdas hanyalah merupakan sebuah telepon yang menyajikan fitur canggih seperti surel (surat elektronik), internet dan kemampuan membaca buku elektronik (e-book) atau terdapat papan ketik (baik sebagaimana jadi maupun dihubung keluar) dan penyambung VGA. Dengan kata lain, ponsel cerdas merupakan komputer kecil yang mempunyai kemampuan sebuah telepon.

(https://id.wikipedia.org/wiki/Ponsel_cerdas di unduh pada tanggal 1 Mei 2020)

Dasiroh dalam Jurnal Medium Sartika (2018) mengatakan mengikuti perkembangan teknologi digital, kini handphone tidak hanya digunakan sebagai alat untuk berkomunikasi melalui panggilan dan sms saja, namun lebih dari itu, kemajuan teknologi digital ini telah melahirkan handphone terbaru yang memiliki multi fungsi yaitu smartphone.

Salah satu fitur yang dapat dinikmati dalam smartphone adalah aplikasi WhatsApp, merupakan sebuah aplikasi yang digunakan sebagai media chatting, call, dan video call, yang disertai dengan kemampuan pengiriman document foto, video dan file serta audio. Fitriah (2020) dalam artikelnya menjelaskan bahwa WhatsApp menjadi aplikasi chat paling populer saat ini. Aplikasi ini kabarnya digunakan oleh 1,5 miliar pengguna diseluruh dunia. Bahkan menurut laporan Sensor Tower, WhatsApp menjadi aplikasi yang paling banyak 
diunduh di Play Store dan App Store selama 2019.

Fitria (2020) juga menyebutkan bahwa WhatsApp awalnya didirikan oleh dua mantan karyawan Yahoo!, Brian Acton dan Jan Koum. Aplikasi kemudian diluncurkan pertama pada November 2009, setelah pengujian. Awalnya, WhatsApp hanya eksklusif hadir di App Store. Hingga selang beberapa tahun kehadiran WhatsApp semakin dicintai pengguna. Bahkan pada 2013, WhatsApp mengklaim memiliki 400 juta pengguna aktif. Pada 19 Februari 2014, Facebook, Inc. mengakuisisi WhatsApp sebesar USD19 miliar. Ini merupakan salah satu akuisisi terbesar hingga saat ini.

\section{Efektifitas Komunikasi Interpersonal}

Menurut Devito (1997), adapun pemaparan kualitas umum tersebut dapat dijelaskan sebagai berikut :

1. Keterbukaan merupakan keinginan atau kesediaan tiap individu untuk memberitahukan, menceritakan antara lain

a. Komunikator interpersonal yang efektif harus terbuka kepada orang yang diajaknya berinteraksi.

b. Kesediaan komunikator untuk bereaksi secara jujur terhadap stimulus yang datang. Orang yang diam, tidak kritism dan tidak tanggap pada umumnya merupakan peserta percakapan yang menjemukan.

c. Menyangkut "kepemilikan" perasaan dan pikiran. Dalam hal ini berarti mengakui bahwa perasaan dan pikiran yang dilontarkan adalah memang "milik" kita dan kita bertanggung jawab atasnya.

2. Empati Menurut Henry Backrack, empati adalah kemampuan seseorang untuk mengetahi apa yang sedang dialami orang lain pada suatu saat tertentu, dari sudut pandang orang lain tersebut.

3. Sikap Mendukung, Hubungan interpersonal yang efektif adalah hubungan dimana terdapat sikap mendukung (supportiveness). Adapun yang termasuk dalam sikap adalah (1) deskriptif, bukan evaluatif, (2) spontan, bukan strategic, dan (3) provisional, bukan sangat yakin.

4. Sikap Positif, Kita mengkomunikasikan sikap positif dalam komunikasi interpersonal dengan sedikitnya dua cara: (1) menyatakan sikap positif dan (2) secara positif mendorong orang yang menjadi teman kita berinteraksi.

5. Kesetaraan, terlepas dari ketidaksetaraan ini, komunikasi interpersonal akan lebih efektif bila suasananya setara.

\section{Media Pembelajaran}

Rusman yang dikutip dalam jurnal Sartika (2018) mengemukakan bahwa ada lima jenis media yang dapat digunakan dalam pembelajaran :

1. Media Visual, adalah media yang hanya dapat dilihat dengan menggunakan indra penglihatan yang terdiri dari atas media yang diproyeksikan dan media yang tidak dapat diproyeksikan yang biasanya berupa gambar diam atau gambar bergerak.

2. Media Audio, yaitu media yang mengandung pesan dalam bentuk auditif yang dapat merangsang pikiran, perasaan, perhatian, dan kemauan para peserta didik untuk mempelajari bahan ajar. Contoh dari media audio ini adalah program kaset suara dan program radio.

3. Media Audio-Visual, yaitu media yang merupakan kombinasi audio dan visual atau biasa disebut media pandangdengar. Contoh dari media audio-visual adalah program video/televisi dan program slide suara (sound slide).

4. Kelompok Media Penyaji, media ini sebagaimana diungkapkan Donald $\mathrm{T}$. Tosti dan John R. Ball dikelompokkan ke dalam tujuh jenis, yaitu : (a) kelompok kesatu ; grafis, bahan cetak, dan gambar diam, (b) kelompok kedua ; media proyeksi diam, (c) kelompok ketiga; media audio, (d) kelompok keempat ; media audio, (e) kelompok kelima ; media gambar hidup/film, (f) 
kelompok keenam ; media televisi, dan (g) kelompok ketujuh; multimedia.

5. Media objek dan media interaktif berbasis komputer. Media objek merupakan media tiga dimensi yang menyampaikan informasi tidak dalam bentuk penyajian, melainkan melalui ciri fisiknya sendiri, seperti ukurannya, bentuknya, beratnya, susunannya, warnanya, fungsinya, dan sebagainya. ${ }^{1}$

Dari pendapat Rusman tersebut maka dapat dikatakan bahwa media WhatsApp sudah memiliki kelima jenis media pembelajaran tersebut dalam satu aplikasi saja.

\section{METODE PENELITIAN}

Desain penelitian yang digunakan peneliti adalah kualitatif dengan pendekatan deskriptif. Bogdan dan Taylor (dalam Moeleong, 2007:4) mendefinisikan metodologi kualitatif sebagai prosedur penelitian yang menghasilkan data deskriptif yang berupa kata-kata tertulis atau tulisan dari orang-orang dan perilaku yang dapat diamati. Penelitian ini berfokus pada deskripsi yang menjelaskan efektivitas komunikasi interpersonal dalam Kegiatan Pembelajaran Melalui Media WhatsApp Group dengan studi kasus pada mahasiswa semester 2 program studi Ilmu Komunikasi UIN Raden Fatah Palembang. Adapun narasumber dalam penelitian ini yang tidak mau disebutkan namanya terdiri dari 7 orang yang diantaranya adalah sebagai berikut:

Tabel 1. Daftar Narasumber

\begin{tabular}{|c|l|lc|}
\hline No & Nama & \multicolumn{2}{|c|}{ Peran } \\
\hline 1 & \multirow{2}{*}{ MMF } & $\begin{array}{l}\text { Dosen Prodi } \\
\text { Komunikasi } \\
\text { Raden Fatah }\end{array}$ & UIN \\
\hline 2 & EG & $\begin{array}{l}\text { Dosen Prodi } \\
\text { Komunikasi } \\
\text { Raden Fatah }\end{array}$ & UIN \\
\hline
\end{tabular}

\begin{tabular}{|c|l|l|}
\hline 3 & DF & $\begin{array}{l}\text { Mahasiswa Prodi } \\
\text { Ilmu Komunikasi } \\
\text { UIN Raden Fatah }\end{array}$ \\
\hline 4 & WS & $\begin{array}{l}\text { Mahasiswa Prodi } \\
\text { Ilmu Komunikasi } \\
\text { UIN Raden Fatah }\end{array}$ \\
\hline 5 & MAA & $\begin{array}{l}\text { Mahasiswa Prodi } \\
\text { Ilmu Komunikasi } \\
\text { UIN Raden Fatah }\end{array}$ \\
\hline 6 & TO & $\begin{array}{l}\text { Mahasiswa Prodi } \\
\text { Ilmu Komunikasi } \\
\text { UIN Raden Fatah }\end{array}$ \\
\hline 7 & MK & $\begin{array}{l}\text { Mahasiswa Prodi } \\
\text { Ilmu Komunikasi } \\
\text { UIN Raden Fatah }\end{array}$ \\
\hline
\end{tabular}

Sumber : Hasil Observasi, 2020

\section{HASIL PENELITIAN DAN PEMBAHASAN}

Berdasarkan hasil wawancara yang dilakukan kepada seluruh narasumber, diketahui bahwa kegiatan perkuliahan dengan menggunakan WhatsApp Group yang dilakukan oleh dosen dan mahasiswa dirasakan belum efektif, kegiatan WhatsApp Group merupakan sebuah sarana pendukung untuk kemudahan penyampaian pesan seperti pemberian tugas secara instan dan penerimaan tugas secara instan, akan tetapi dalam kegiatan pembelajaran kegiatan perkulian dengan menggunakan WhatsApp Group mengalami banyak kendala.

Rusman yang dikutip dalam jurnal Sartika (2018) mengemukakan bahwa Ada lima jenis media yang dapat digunakan dalam pembelajaran,

1. Media Visual, adalah media yang hanya dapat dilihat dengan menggunakan indra penglihatan yang terdiri dari atas media yang diproyeksikan dan media yang tidak dapat diproyeksikan yang biasanya berupa gambar diam atau gambar bergerak.

2. Media Audio, yaitu media yang mengandung pesan dalam bentuk auditif yang dapat merangsang pikiran, perasaan, perhatian, dan kemauan para peserta didik untuk mempelajari bahan 
ajar. Contoh dari media audio ini adalah program kaset suara dan program radio.

3. Media Audio-Visual, yaitu media yang merupakan kombinasi audio dan visual atau biasa disebut media pandangdengar. Contoh dari media audio-visual adalah program video /televisi dan program slide suara (sound slide).

4. Kelompok Media Penyaji, media ini sebagaimana diungkapkan Donald $\mathrm{T}$. Tosti dan John R. Ball dikelompokkan ke dalam tujuh jenis, yaitu : (a) kelompok kesatu ; grafis, bahan cetak, dan gambar diam, (b) kelompok kedua ; media proyeksi diam, (c) kelompok ketiga; media audio, (d) kelompok keempat ; media audio, (e) kelompok kelima ; media gambar hidup/film, (f) kelompok keenam ; media televise, dan (g) kelompok ketujuh ; multimedia.

5. Media objek dan media interaktif berbasis komputer. Media objek merupakan media tiga dimensi yang menyampaikan informasi tidak dalam bentuk penyajian, melainkan melalui ciri fisiknya sendiri, seperti ukurannya, bentuknya, beratnya, susunannya, warnanya, fungsinya, dan sebagainya. ${ }^{2}$

Dari apa yang dijelaskan oleh Rusman diketahui bahwa mahasiswa diketahui dapat menerima beberapa jenis media pembelajaran melalui kegiatan perkuliahan menggunakan WhatsApp Group, adapun media yang dapat diterima oleh mahasiswa diantaranya adalah media visual, media audio, media audio visual dan media penyaji sedangkan media objek tidak dapat dilakukan menggunakan media pembelajaran menggunakan WhatsApp Group, hasil wawancara yang dilakukan oleh Bapak MMF selaku dosen pengampuh mata kuliah di Prodi Ilmu Komunikasi yang menggunakan media WhatsApp Group menjelaskan bahwa beliau merasa dari sekian banyak kemudahan yang disediakan oleh WhatsApp Group tetap saja WhatsApp Group tidak dapat menampilkan media objek, beliau mengatakan bahwa dalam mata kuliah yang diampuhnya beliau harus memperlihatkan atau menunjukkan bahwa manusia juga dapat berkomunikasi hanya dengan menggunakan seluruh indera. Akan tetapi terdapat beberapa indera yang tidak dapat diperagakan seperti indera penciuman sebagai informasi mengenai bau, indera peraba sebagai informasi mengenai bentuk dan pola terhadap suatu benda dan sebagainya.

Lain halnya dengan Bapak MMF, Ibu EG mengungkapkan bahwa menggunakan WhatsApp Group beliau tidak ada masalah dengan penyampaian berbagai bentuk media yang dapat disampaikan, karena dengan menggunakan media WhatsApp Group Ibu EG masih bisa menyampaikan power pointnya kepada mahasiswa, memberikan berbagai jenis contoh video dan pesan suara sehingga jika dikaji dalam hal media maka WhatsApp Group sudah dapat menyediakan ruang tersebut.

Mahasiswa MAA mengemukakan bahwa beliau menerima semua jenis materi baik itu berupa bentuk video, gambar atau dokumen yang disampaikan melalui Media WhatsApp Group akan tetapi, media yang disampaikan tidak dapat dipahami dengan jelas tanpa adanya penjelasan langsung yang diberikan oleh dosen. Terkadang hasil paparan materi yang disampaikan melalui tulisan sudah terlewat jauh sehingga mahasiswa kesulitan untuk melakukan scroll ulang pada text yang sudah lama terlewat. Pernyataan MAA tersebut dipertegas oleh pernyataan yang dikemukakan oleh TO dan MK yang memiliki pendapat kurang lebih sama, bahwa media yang disampaikan pada dasarnya sampai dengan cepat kepada mahasiswa akan tetapi mahasiswa merasa kesulitan memahami maksud materi tanpa adanya penjelasan langsung yang diberikan oleh dosen.

DF berpendapat bahwa media WhatsApp Group memang mampu menyediakan berbagai materi dengan cepat dari jarak jauh, tetapi keterbatasan pemahaman mahasiswa, membuat mahasiswa merasa bahwa media pembelajaran yang disampaikan tidak 
efektif, ini dikarenakan pesan yang masuk dalam WhatsApp Group yang berupa materi belajar terkadang masuk bersamaan dengan pesan lainnya sehingga hal ini memecah fokus mahasiswa dan membuat konsentrasi mahasiswa menjadi terganggu, bagi mahasiswa yang fokus terhadap jam pelajaran dan materi yang dipaparkan hal ini masih dalam batas yang wajar, akan tetapi bagi mahasiswa yang tidak mampu berkonsentrasi apabila ada gangguan belajar maka hal ini akan membuat mahasiswa untuk meninggalkan kegiatan belajar dalam WhatsApp Group dan melanjutkan membalas pesan lainnya yang dianggapnya lebih menarik.

WS mengatakan bahwa beliau senang dengan metode pembelajaran yang hanya menggunakan media WhatsApp Group akan tetapi materi yang disampaikan kerap terabaikan karena mahasiswa terlena dengan fleksibilitas waktu dalam kegiatan perkuliahan, sehingga timbul kelalaian bagi mahasiswa untuk melaksanakan pembelajaran melalui materi yang disampaikan oleh dosen menggunakan media WhatsApp Group.

Berdasarkan paparan dari hasil wawancara yang dikemukan oleh narasumber, maka diketahui bahwa media pembelajaran yang disampaikan oleh dosen ke mahasiswa melalui WhatsApp Group sebetulnya dapat tersampaikan dengan cepat kepada seluruh mahasiswa, akan tetapi mahasiswa masih merasa kesulitan untuk fokus dalam kegiatan perkuliahan, karena dosen tidak bisa memantau secara seksama siapa saja dari mahasiswa yang betul-betul menyimak perkuliahan yang sedang berlangsung menggunakan media WhatsApp Group. Mahasiswa dan dosen akan mendapatkan mahasiswa dapat memahami lebih banyak mengenai berbagai materi pembelajaran dari seluruh jenis media apabila penggunaan WhatsApp Group digunakan sebagai pelengkap kegiatan pembelajaran yang dilakukan secara tatap muka langsung dalam kelas.

Berikut merupakan paparan kualitas umum efektivitas komunikasi interpersonal dalam melaksanakan pembelajaran menggunakan media WhatsApp Group berdasarkan kualitas Umum yang dikemukakan oleh Devito (1997):

1. Opennes, berdasarkan hasil wawancara yang dilakukan kepada dosen dan mahasiswa yang menggunakan media WhatsApp Group untuk melakukan kegiatan perkuliahan diketahui bahwa mahasiswa sulit untuk terbuka, pada pemaparan yang disampaikan oleh Devito keterbukaan disini maksudnya adalah mahasiswa bersedia untuk menyampaikan aspirasi dan perasaanya berkaitan dengan materi ajar yang disampaikan. Dosen merasa kesulitan untuk memberikan stimulus kepada mahasiswa agar bersedia aktif, meskipun dengan berbagai jenis stimulasi seperti reward nilai yang baik apabila mahasiswa aktif. Mahasiswa cenderung kaku, dan menjawab secara text book setiap pertanyaan yang dilontarkan, ini dikarenakan mahasiswa merasa bahwa akan lebih mudah menemukan jawaban apabila melakukan searching sehingga mahasiswa cenderung malas berfikir dan menstimulasi otaknya untuk menganalisis sebuah materi yang disampaikan. Mahasiswa pada umumnya cenderung memilih aman dengan memilih diam dan tidak bersuara apabila mahasiswa merasa tidak tahu atau mengalami kendala pemahaman, mahasiswa merasa bahwa perkuliahan memang penting tetapi untuk menyampaikan apa yang mahasiswa rasakan saat melakukan kegiatan perkuliahan dengan menggunakan media WhatsApp Group sulit untuk dilakukan. Berdasarkan kualitas Umum openness diketahui bahwa mahasiswa kesulitan untuk menyampaikan bagaimana pendapatnya, dan untuk menghindari masalah mahasiswa lebih baik diam dan mengikuti alur saja, banyak mahasiswa yang melakukan kegiatan copy paste terhadap materi sehingga ketika 
ditanyakan secara mendetil mahasiswa tidak dapat menjelaskan dengan baik dan hal ini akan mengakibatkan pembelajaran tidak efektif dalam hal openness.

2. Empati, Dalam penelitian ini diketahui bahwa dosen pada program studi Ilmu Komunikasi UIN Raden Fatah Palembang sudah merasakan apa yang dirasakan oleh mahasiswa ketika melaksanakan kegiatan perkuliahan dengan menggunakan media WhatsApp Group akan tetapi dosen tidak mampu mengkaji terlalu dalam karena sulit untuk mengidentifikasi mahasiswa yang betul-betul melaksanakan kegiatan perkuliahan ataupun mahasiswa yang hanya terlihat aktif tetapi sebetulnya tidak aktif sama sekali. Mahasiswamahasiswa program studi Ilmu Komunikasi UIN Raden Fatah Palembang merasa bahwa sebetulnya mereka memahami bahwa dosen yang mengampuh mata kuliah sudah memberikan motivasi dan paparan materi yang disesuaikan dengan metode yang diharapkan oleh mahasiswa, akan tetapi mahasiswa tidak dapat merasakan kedekatan seperti yang dirasakan apabila kegiatan pembelajaran dilakukan secara langsung di dalam kelas, padahal kedekatan yang ditimbulkan dalam proses belajar mengajar sangat dibutuhkan untuk menumbuhkan keinginan dan semangat dalam diri mahasiswa untuk melaksanakan pelajarannya.

3. Supportivenes, diketahui bahwa mahasiswa program studi Ilmu Komunikasi UIN Raden Fatah Palembang juga belum efektif, ini dikarenakan mahasiswa yang bersikap pasif, dan menjawab hanya berdasarkan text book, mahasiswa sulit untuk terangsang untuk terlihat antusias dalam melaksanakan kegiatan perkuliahan, meskipun terdapat beberapa mahasiswa yang antusias akan tetapi sebagaian besar terlihat tidak antusias. Kegiatan pembelajaran yang dilakukan dengan menggunakan WhatsApp Group oleh nya tidak mendapati sikap suportif yang besar dari sebagian besar mahasiswa, mahasiswa cenderung menjawab secara evaluatif dan tidak terlalu mendetail, persoalan lainnya adalah mahasiswa sulit untuk menjawab secara spontan dan berupaya mencari jawaban yang mereka temukan di media internet terlebih dahulu dari pada harus menganalisis sendiri jawaban yang akan disampaikan. Mahasiswa pun juga tidak bisa dengan spontan dalam memberikan pertanyaan karena terpaksa membaca materi berulang-ulang terlebih dahulu baru dapat dipahami, selain itu mahasiswa juga merasa bahwa dosen seringkali menjawab secara evaluatif.

4. Sikap Positif, diketahui bahwa sebagian besar mahasiswa program studi Ilmu Komunikasi UIN Raden Fatah Palembang menunjukkan sikap yang sebaliknya dari sikap yang diharapkan oleh dosen pengampuh mata kuliah, dimana sikap yang diharapkan adalah sikap antusias dalam belajar, dan fokus terhadap kegiatan belajar pada saat kegiatan pembelajaran menggunakan media WhatsApp Group berlangsung. Mahasiswa cenderung bersikap sebaliknya dengan apa yang diharapkan, mahasiswa yang melaksanakan kegiatan perkuliahan dengan menggunakan media WhatsApp Group tidak seantusias apabila melakukan kegiatan perkuliahan secara tatap muka langsung di kelas. Mahasiswa diharapkan secara aktif akan tetapi sebagian besar mahasiswa malah cenderung pasif dan hal ini merukapakan kendala yang sangat sulit untuk dihindari apabila melakukan kegiatan pembelajaran jarak jauh terlebih hanya menggunakan pesan text saja maka hal ini akan lebih memperburuk keadaan.

5. Kesetaraan, perilaku yang menunjukkan ketidaksetaraan tujuan oleh dosen dan mahasiswa pada saat melaksanakan kegiatan perkuliahan menggunakan 
WhatsApp Group, dosen beranggapan bahwa materi yang disampaikan merupakan hal yang sangat penting untuk disampaikan kepada mahasiswa sehingga mahasiswa harus mampu memami konsep materi perkuliahan, sedangkan mahasiswa mayoritas beranggapan absensi yang dilakukan pada saat perkuliahan berlangsunglah yang lebih penting, sedangkan pemahaman materi bisa dilakukan saat hendak melaksanakan ujian saja.

Perbedaan konsep pemahaman tujuan antara dosen dan mahasiswa akan sulit dihindari karena mahasiswa tidak dapat secara penuh merasakan emosi yang timbul dalam diri dosen paa saat menyampaikan materi, begitupula dengan dosen, dosen merasa kesulitan memahami apa yang diinginkan oleh mahasiswa sehingga sulit untuk menyamakan tujuan dalam kegiatan pembelajaran dengan menggunakan media WhatsApp Group.

\section{PENUTUP}

Berdasarkan dari hasil pemaparan mengenai efektivitas komunikasi interpersonal dalam kegiatan perkuliahan menggunakan WhatsApp Group oleh dosen Program Studi Ilmu Komunikasi Universitas Islam Negeri Raden Fatah Palembang diketahui bahwa WhatsApp Group dapat menampilkan berbagai jenis media pembelajaran baik itu berupa media visual, audio, audio visual, dan kelompok penyaji. Akan tetapi media WhatsApp Group tidak dapat memberikan contoh objek secara langsung apabila matakuliah membutuhkan contoh objek untuk diperagakan. Penelitian ini menunjukkan bahwa kegiatan belajar yang hanya menggunakan media WhatsApp Group tanpa menggunakan metode perkuliahan tatap muka menjadi tidak efektif, ini dikarenakan banyaknya kendala yang dihadapi oleh mahasiswa dan dosen saat pelaksanaan kegiatan perkuliahan berlangsung. Berbagai kendala yang dihadapi adalah tingkat keterbukaan yang kecil dari mahasiswa, empati yang sulit untuk ditunjukkan baik oleh mahasiswa maupun oleh dosen, sikap dukungan yang tidak sekuat apabila pembelajaran dilakukan dengan pertemuan langsung dikelas, sikap yang ditunjukkan sebagian besar berlaku sebaliknya dengan apa yang diharapkan oleh dosen, serta kesetaraan makna materi pembelajaran baik itu bagi mahasiswa maupun bagi dosen yang berbeda.

Diketahui bahwa mahasiswa sulit untuk terbuka, mahasiswa tidak dapat merasakan kedekatan seperti yang dirasakan apabila kegiatan pembelajaran dilakukan secara langsung di dalam kelas, padahal kedekatan yang ditimbulkan dalam proses belajar mengajar sangat dibutuhkan untuk menumbuhkan keinginan dan semangat dalam diri Mahasiswa untuk melaksanakan pelajarannya.

Sebagian besar Mahasiswa program studi Ilmu Komunikasi Universitas Islam Negeri Raden Fatah Palembang menunjukkan sikap yang sebaliknya dari sikap yang diharapkan selain itu mahasiswa sulit untuk terangsang untuk terlihat antusias dalam melaksanakan kegiatan perkuliahan, meskipun terdapat beberapa mahasiswa yang antusias akan tetapi sebagaian besar terlihat tidak antusias.

Perbedaan konsep pemahaman tujuan antara dosen dan mahasiswa akan sulit dihindari karena mahasiswa tidak dapat secara penuh merasakan emosi yang timbul dalam diri dosen pada saat menyampaikan materi, begitupula dengan dosen, dosen merasa kesulitan memahami apa yang diinginkan oleh mahasiswa sehingga sulit untuk menyamakan tujuan dalam kegiatan pembelajaran dengan menggunakan media WhatsApp Group.

\section{DAFTAR PUSTAKA}

Deddy, Mulyana. 2010. Ilmu Komunikasi Suatu Pengantar, Cet. XIV. Bandung, PT. Remaja Rosdakarya, h. $68-69$

Devito, Joseph A. 2011. Komunikasi Antar Manusia. Pamulang-Tangerang. Selatan, Karisma Publishing Group 
Effendy Onong Uchajana. 2002. Ilmu Komunikasi Teori dan Praktek. Bandung, PT Rosdakarya

Fitriah, Maria.2020. Opini : Transformasi Media pembelajaran pada masa Pandemi Covid19.www.liputan6.com https://www.liputan6.com/citizen6/re ad/4248063/opini-transformasimedia-pembelajaran-pada-masapandemi-covid-19\#

Moleong, Lexy J. 2007. Metodologi Penelitian Kualitatif. Bandung, Penerbit PT Remaja Rosdakarya. Offset

Sartika. 2018. Kegunaan WhatsApp sebagai Media Informasi. Dan Media Pembelajaran pada Mahasiswa Ilmu Komunikasi Stisip Persada Bunda. Jurnal Ilmiah Fakultas Komunikasi Universitas Islam Riau. Volume 6 No 2. E-ISSN : 26151308 PISSN:23030194
Severin, Werner J dan James.W. Tankard, Jr. 2011. Teori Komunikasi Sejarah,. Metode dan Terapan didalam Media Massa. Jakarta, Kencana

Trisnani. 2017. Pemanfaatan WhatsApp sebagai Media Komunikasi dan Kepuasan dalam Penyampaian pesan di Kalangan Tokoh Masyarakat.Jurnal Kominfo.co.id. Volume 6 : No 3

Untari, Pernita Hestin. 2020. Sejarah WhatsApp aplikasi popular saat ini. Tecknookezone.com https://techno.okezone.com/read/202 0/01/18/207/2154693/sejarahwhatsApp-aplikasi-chat-palingpopuler-saat-ini

Aplikasi Data Penyebaran Kasus Covid-19 Di dunia, di unduh pada tanggal 12 Mei 2020

https://news.google.com/covid19/ma $\mathrm{p} ? \mathrm{hl}=\mathrm{id} \& \mathrm{gl}=\mathrm{ID} \&$ ceid $=\mathrm{ID} \% 3$ Aid\&mi $\mathrm{d}=\% 2 \mathrm{Fm} \% 2 \mathrm{~F} 03 \mathrm{ryn}$ 
Jurnal Professional FIS UNIVED Vol.7 No.1 Juni 2020 